\title{
NITROGEN, PHOSPHORUS AND POTASSIUM ACCUMULATION IN WATERMELON CULTIVARS IRRIGATED WITH SALINE WATER
}

\author{
Andréa R. F. C. da Costa ${ }^{1 *}$, José F. de Medeiros ${ }^{2}$ \\ 1*Corresponding author. Universidade Federal Rural do Semi-Árido/ Mossoró - RN, Brasil. E-mail: andrearaquel19@ @otmail.com
}

\section{KEYWORDS}

Citrullus lanatus, plant nutritional status, water management

\begin{abstract}
The use of saline water in agriculture has increased in the Brazilian semiarid due to low availability of good quality water for irrigated agriculture, being the selection of salt tolerant hybrids an alternative to reduce the effect of salinity on nutritional status of plants. So, the objective of this work was to evaluate the effect of salinity of irrigation water in the accumulation and partition of nutrients in the vegetable tissue of watermelon cultivars, in the region of Mossoro in the State of Rio Grande do Norte, Brazil. The treatments studied consisted of applying irrigation water with five electrical conductivities $\left(\mathrm{EC} 1=0.57, \mathrm{EC} 2=1.36, \mathrm{EC} 3=2.77, \mathrm{EC} 4=3.86\right.$ and $\left.\mathrm{EC} 5=4.91 \mathrm{dS} \mathrm{m}^{-1}\right)$, two watermelon cultivars and four samplings times (15;29; 43 and 60 days after transplanting), arranged in a scheme of split plot $(5 \times 2 \times 4)$ and outlined in complete blocksrandomized with four replications.The accumulated nutrients in plants were influenced by $\mathrm{ECw}$, occurring a loss in comparison with the higher $\mathrm{ECw}$ of 24.1 and $36.4 \%$ in the accumulationof $\mathrm{N}$ and $\mathrm{P}$ in the vegetative part of plant and 37.8 and $30.1 \%$ in the accumulation of $\mathrm{P}$ and $\mathrm{K}$ in the aerial part. The accumulation of $\mathrm{N}, \mathrm{P}$ and $\mathrm{K}$ in the watermelon was influenced by plant age, with reduction at the end of the cycle.
\end{abstract}

\section{INTRODUCTION}

In recent years, watermelon has been one of the most important crops cultivated in Brazil especially in the Northeast Region. In this region the culture found excellent conditions for its development due to the edaphoclimatic conditions and the availability of springs water underground and on the surface (Martins et al., 2013), and it can be cultivated the whole year under irrigated conditions.

In Rio Grande do Norte and Ceara, large melonproducing companies started planting this crop targeting, above all, the external market. The Quetzali watermelon is one of the most produced by the fruit producing companies in this region and the main exported variety with seed.

Currently seedless watermelon is also a widely accepted product in the world's major markets and has emerged as an alternative crop for growers. In Mossoro region the cultivated area in recent years has grown substantially to 2000 ha (Costa et al., 2013).

The region presents not only conducive conditions to cultivation, but also availability of water. The available water in the region obtained at a compatible cost comes from a well that explores the Jandaira aquifer which has the disadvantage of having high salt contents. In this sense, water salinity has been identified as one of the main factors responsible for hindering the expansion and productivity of crops that use irrigation (Furtardo et al., 2012).

The presence of excess ions in the soil can prevent the absorption of essential elements to plant growth leading to nutritional imbalance. Salinity may promote nutritional imbalance due to excess sodium in the soil solution that causes disturbance in nutrient uptake by the plant (Wanderley et al., 2010), impairing mainly root absorption of $\mathrm{K}$ and interfering with its physiological functions. However, the greater demand for water led to the use of the most water sources available in the region forcing the producers to use water with different levels of salinity (Costa et al., 2012).

The use of water with high concentrations of salts in irrigation is one of the great challenges of researchers and agricultural producers, mainly due to the scarcity of good quality water, seeking to obtain economically viable productivities and quality products using water of inferior quality (Medeiros et al., 2014).

An alternative to reduce the effect of salts on plants would be the selection of salinity tolerant hybrids. The tolerance of the cultivars to the salinity is related to the ability of the plant to resist certain levels of salts which

\footnotetext{
${ }^{2}$ Universidade Federal Rural do Semi-Árido/ Mossoró - RN, Brasil. 
may vary according to the genotype, its development phase, nature and intensity of saline stress (Brito et al., 2014; Oliveira et al., 2015). The ability of plant genotypes to maintain high nutrient contents and low levels of $\mathrm{Na}$ within the tissue is one of the mechanisms that contribute to express greater tolerance to salinity. Due to the genetic variability of olericulture hybrids such as melon and watermelon, for example, there is a great variation in the tolerance to salinity between the cultivars of these crops (Silva et al., 2005).

Considering the above, this study was developed to evaluate the effect of water salinity irrigation on the accumulation and partition of nitrogen $(\mathrm{N})$, phosphorus $(\mathrm{P})$ and potassium $(\mathrm{K})$ in two watermelon cultivars with different grades of tolerance to salinity.

\section{MATERIAL AND METHODS}

The experiment was carried out at the Experimental Farm "Rafael Fernandes" belonging to the Semi-Arid Federal Rural University (UFERSA), located in Alagoinha, in the municipality of Mossoro-RN, at latitude 5'03'37' S and longitude $37^{\circ} 23$ ' $50^{\prime \prime}$ W Gr, with an altitude of approximately $72 \mathrm{~m}$.

The experimental area soil is classified as a RedYellow Argisol, according to the classification proposed by Embrapa (2006). The available irrigation water at the Experimental Farm comes from a well drilled from the Açu Sandstone aquifer with water electric conductivity $(\mathrm{ECw})$ around $0.57 \mathrm{dS} \mathrm{m}^{-1}$.

The treatments consisted in the application of water irrigation with five salt concentrations (equivalent to electrical conductivities of $0.57 ; 1.36 ; 2.77 ; 3.86$ and 4.91 $\mathrm{dS} \mathrm{m}^{-1}$ ), two watermelon cultivars (Quetzali and Shadow) and four plant sampling time $(15 ; 29 ; 43$ and 60 days after transplanting), arranged in a $5 \times 2 \times 4$ sub - divided plots scheme and completely randomized blocks with four replications.

The lower salinity water (S1) came from the deep artesian well and the higher one (S5) was previously produced in a $5000 \mathrm{~L}$ tank with the $\mathrm{NaCl}, \mathrm{CaCl} .2 \mathrm{H}_{2} \mathrm{O}$ and $\mathrm{MgSO}_{4} .7 \mathrm{H}_{2} \mathrm{O}$ that the $\mathrm{mol}_{\mathrm{c}}$ ratio of $\mathrm{Na}, \mathrm{Ca}$ and $\mathrm{Mg}$ was $7: 2: 1$. The proportionality used for $\mathrm{Na}: \mathrm{Ca}: \mathrm{Mg}$ is a representative approximation of the majority water sources available for irrigation in the Brazilian Northeast. The other three levels obtained of water salts were from the mixture of these two waters, being monitored daily by means of a portable conductivity meter from collected samples during irrigation in emitters distributed in the area.

The culture used in the experiment was the watermelon (Citrulluslanatus), cultivars Quetzali (with seeds) and Shadow (seedless). The choice of the cultivars for planting took into account the type of preferred fruit by the consumer market, their resistance to transportation, adaptation of cultivars to the region and tolerance to diseases. The commercial crops of watermelon in Brazil are cultivars of American or Japanese origin that have adapted well to our edapho-climatic conditions. Currently in the States of Rio Grande do Norte and Ceará the cultivars Shadow and Quetzali have been well cultivated.

The sowing was done in polyethylene trays for 200 seedlings filled with commercial substrate based on coconut fiber and the transplanting occurred at 14 days after sowing.
The experimental plots consisted of three rows of $20 \mathrm{~m}$ of plants with spacing of $2.0 \mathrm{~m}$ between rows and 0.5 $\mathrm{m}$ between plants. The arrangement of the plants was done in such way as to maintain a seeded fruit plant, in the case of the Quetzali cultivar, alternated with a seedless plant, Shadow cultivar in each line of the experimental plot. A row of plants was used to collect the material. For each cultivar we selected the plant randomly, before starting the harvest at each time, corresponding to the sub-subplot.

The irrigation system used in the experiment was drip irrigation. For each row of plant there was a lateral line of drippers, spaced $0.3 \mathrm{~m}$, with mean flow of $1.3 \mathrm{~L} \mathrm{~h}^{-1}$ at a pressure of $80 \mathrm{kPa}$. Irrigation management was carried out based on the estimation of the maximum evapotranspiration of the crop (ETm) daily, according to the method proposed by FAO 56 (Allen et al., 2006), adding a leaching blade of $10 \%$. Daily climatic data were from a local weather station.

Plant material collections were performed at 15, 29, 43 and 60 days after transplanting (DAT). In the $2^{\text {nd }}, 3^{\text {rd }}$ and $4^{\text {th }}$ collections the leaves, stems and fruits dry matter were estimated by samples taken from the respective fresh materials which were dried in a forced circulation oven at temperature of $65 \pm 5^{\circ} \mathrm{C}$ until constant mass. At the end we determined plant vegetative dry matter (leaf + stem) and total dry mass of the aerial part (leaf + stem + fruit). In the dry materials the $\mathrm{N}, \mathrm{P}$ and $\mathrm{K}$ contents were determined according to the methodology cited by Embrapa (2009). The accumulated content of $\mathrm{N}, \mathrm{P}$ and $\mathrm{K}$ in the different plants' organs (leaf, stem and fruit) was obtained by the product between the nutrient content and dry phytomass of each part of the plant (g plant $\left.{ }^{-1}\right)$.

Due to the quantitative data it was verified whether the requirements of the model according to the recommendations by Bardin (1994) were satisfied: model additivity, normality, independence and homogeneity of error variance. The models were chosen based on the significance of the regression coefficients, adopting the probability level of $5 \%$ and the coefficients of determination $\left(\mathrm{R}^{2}\right)$.

\section{RESULTS AND DISCUSSION}

\section{Accumulation of nitrogen, phosphorus and potassium in the aerial part}

Table 1 shows a summary of the ANOVA for nitrogen, phosphorus and potassium in the vegetative and aerial part of the watermelon plant (NVEG, PVEG, KVEG, NT, PT and KT), as a function of the electrical conductivity of the irrigation water and in different periods of evaluation. It is observed that nitrogen content (NVEG), phosphorus (PVEG) and potassium (KVEG) in the watermelon vegetative part and the content of nitrogen, (NT), phosphorus (PT) and potassium (KT) in the aerial part of the plant were significantly influenced by EC of the irrigation water. There was also a significant effect of the interaction $\mathrm{ECW}$ and watermelon cultivars for $\mathrm{K}$ accumulation in the vegetative part and $\mathrm{N}$ in the aerial part of the plant and the interaction days after the transplanting and cultivars for the $\mathrm{N}, \mathrm{P}$ and $\mathrm{K}$ content in the vegetative part of the watermelon, as well as for the $\mathrm{N}, \mathrm{P}$ and $\mathrm{K}$ content in the aerial part of the plant. 
TABLE 1. Summary of ANOVA and mean values of N, P and K accumulation in the vegetative and aerial part of the watermelon plant (NVEG, PVEG, KVEG, NT, PT and KT), as a function of EC of the irrigation water in different evaluation periods.

\begin{tabular}{|c|c|c|c|c|c|c|c|}
\hline \multirow{2}{*}{ F.V. } & \multirow{2}{*}{$\mathrm{DF}$} & \multicolumn{6}{|c|}{ Variables } \\
\hline & & NVEG & PVEG & KVEG & NT & PT & KT \\
\hline & & \multicolumn{6}{|c|}{ 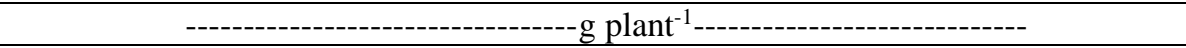 } \\
\hline & & \multicolumn{6}{|c|}{ Statistic F } \\
\hline BLOC & 2 & $0.22^{\mathrm{ns}}$ & $0.82^{\mathrm{ns}}$ & $0.47^{\mathrm{ns}}$ & $0.22^{\mathrm{ns}}$ & $0.22^{\mathrm{ns}}$ & $0.56^{\mathrm{ns}}$ \\
\hline $\mathrm{ECw}$ & 4 & $3.75^{* *}$ & $7.50^{* *}$ & $3.06^{*}$ & $4.12^{* *}$ & $4.71^{* *}$ & $4.08^{* *}$ \\
\hline $\operatorname{ERROR}(\mathrm{A})$ & 8 & --- & --- & --- & --- & --- & --- \\
\hline CULT & 1 & $23.74^{* *}$ & $7.82^{* *}$ & $28.99^{* *}$ & $9.59^{* *}$ & $3.92^{\mathrm{ns}}$ & $8,32^{* *}$ \\
\hline CULTx ECw & 4 & $1.46^{\mathrm{ns}}$ & $1.44^{\mathrm{ns}}$ & $2.60^{*}$ & $2.5^{*}$ & $0.96^{\mathrm{ns}}$ & $2,12^{\mathrm{ns}}$ \\
\hline ERROR(B) & 10 & --- & --- & --- & --- & --- & --- \\
\hline DAT & 3 & $437.57^{* *}$ & $366.56^{* *}$ & $581.48^{* *}$ & $1113.8^{* *}$ & $849.97^{* *}$ & $1290,18^{* *}$ \\
\hline DATxCULT & 3 & $7.67^{* *}$ & $5.55^{* *}$ & $15.92^{* *}$ & $4.16^{* *}$ & $11.54^{* *}$ & $11,14^{* *}$ \\
\hline DATx ECw & 12 & $1.15^{\mathrm{ns}}$ & $0.64^{\mathrm{ns}}$ & $1.16^{\mathrm{ns}}$ & $1.33^{\mathrm{ns}}$ & $1.46^{\mathrm{ns}}$ & $0,97^{\mathrm{ns}}$ \\
\hline DATxCULTx ECw & 12 & $1.29^{\mathrm{ns}}$ & $1.08^{\mathrm{ns}}$ & $0.93^{\text {ns }}$ & $1.22^{\mathrm{ns}}$ & $1.05^{\mathrm{ns}}$ & $0,73^{\mathrm{ns}}$ \\
\hline $\operatorname{ERROR}(\mathrm{C})$ & 60 & --- & --- & --- & --- & --- & --- \\
\hline GENERAL AVERAGE $^{\text {II }}$ & & 7.13 & 5.22 & 7.26 & 7.58 & 5.90 & 7.82 \\
\hline CV1(\%) & & 5.74 & 6.49 & 6.28 & 4.14 & 7.10 & 4.56 \\
\hline CV2(\%) & & 6.35 & 9.40 & 6.12 & 4.65 & 7.44 & 4.92 \\
\hline
\end{tabular}

FV - sources of variation; DF - degrees of freedom - ECW - water electrical conductivity; CULT - cultivar; DAT - days after transplanting; NVEG -nitrogen in the vegetative part of the plant; PVEG - phosphorus in the vegetative part of the plant; KVEG- potassium in the vegetative part of the plant; NT - nitrogen in the aerial part of the plant; PT - phosphorus in the aerial part of the plant; KT - potassium in the aerial part of the plant; ${ }^{n}$-not significant, *- significant at $5 \%$, ** - significant at $1 \%$ probability by $\mathrm{F}$ test; II Values expressed in $1 n$.

The effect of EC of the irrigation water on nutrients content in the watermelon, was observed with the increase of $\mathrm{ECw}$ there was a reduction in nitrogen accumulation and phosphorus in the watermelon vegetative part (Figures $1 \mathrm{~A}$ and $1 \mathrm{~B})$ and on phosphorus and potassium accumulation (Figures 1C and 1D) in the aerial part of the plant, so that the lowest accumulation was for the plants irrigated with higher water EC $\left(5.91 \mathrm{dS} \mathrm{m}^{-1}\right)$ and an average accumulation of $1.07 ; 0.14 ; 0.28 ; 2.07 \mathrm{~g} \mathrm{plant}^{-1}$ and the highest for irrigated plants with lower water EC $\left(0.57 \mathrm{dS} \mathrm{m}^{-1}\right)$ with an average accumulation of $1.41 ; 0.22$; 0.45 and 2.96 g plant $^{-1}$, respectively for NVEG, PVEG, PT and $\mathrm{KT}$.

A.

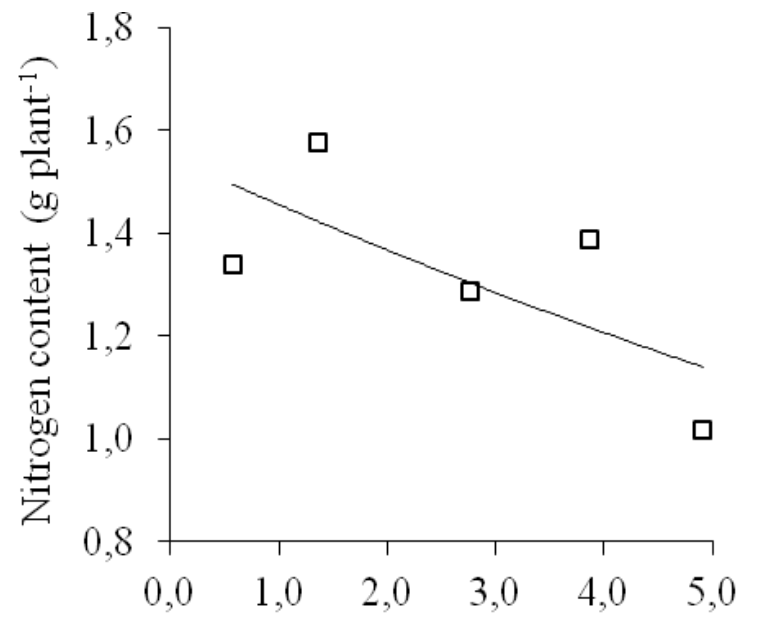

EC in the irrigation water $\left(\mathrm{dS} \mathrm{m}^{-1}\right)$
The lower nutrients extraction in plants under salt stress is mainly due to the growth inhibition caused mainly by the osmotic effects and toxic of salts excess in the root zone (Neves et al., 2009).

Lucena et al. (2011) evaluated the accumulation of macronutrients in Quetzali watermelon cultivated under different levels of salinity in the irrigation water also verified that the accumulation of nitrogen in the total dry matter of the aerial part of the plants decreased linearly with the increase of the salinity in the irrigation water. The reduction in $\mathrm{N}$ accumulation in plants is probably due to the harmful effect of salinity on the accumulation of biomass.

B.

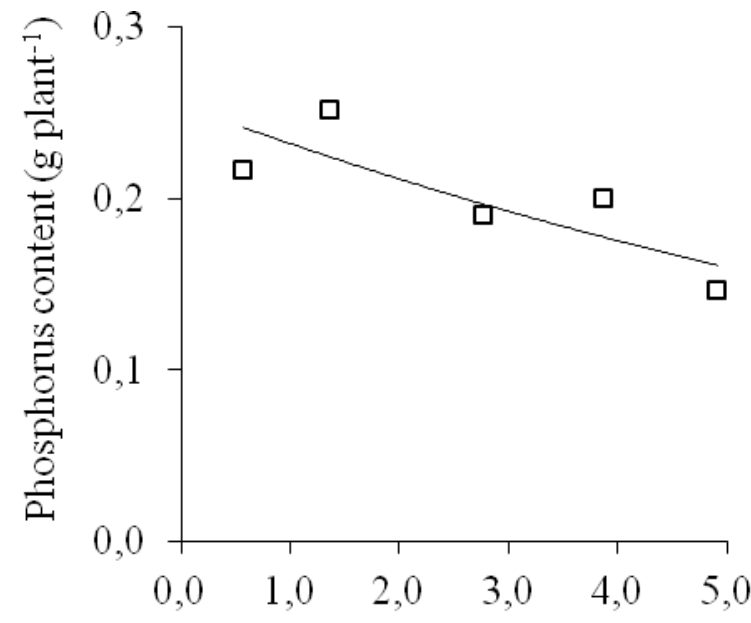

$\mathrm{EC}$ in the irrigation water $\left(\mathrm{dS} \mathrm{m}^{-1}\right)$

\footnotetext{
$-\ln (\mathrm{y})=0.39-0.063 * \mathrm{x}$

$\mathrm{R}^{2}=0.48$
}

$\ln (\mathrm{y})=-1.44-0.090 * * \mathrm{x}$

$\mathrm{R}^{2}=0.73$ 
C.

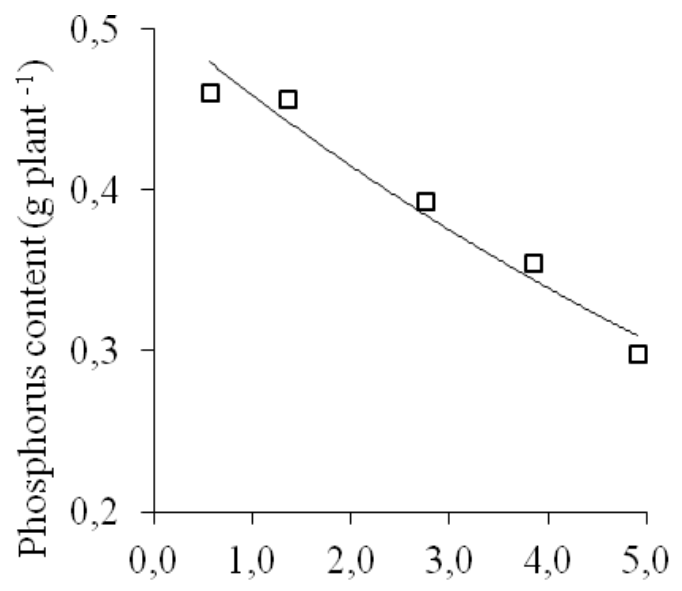

$\mathrm{EC}$ in the irrigation water $\left(\mathrm{dS} \mathrm{m}^{-1}\right)$
D.

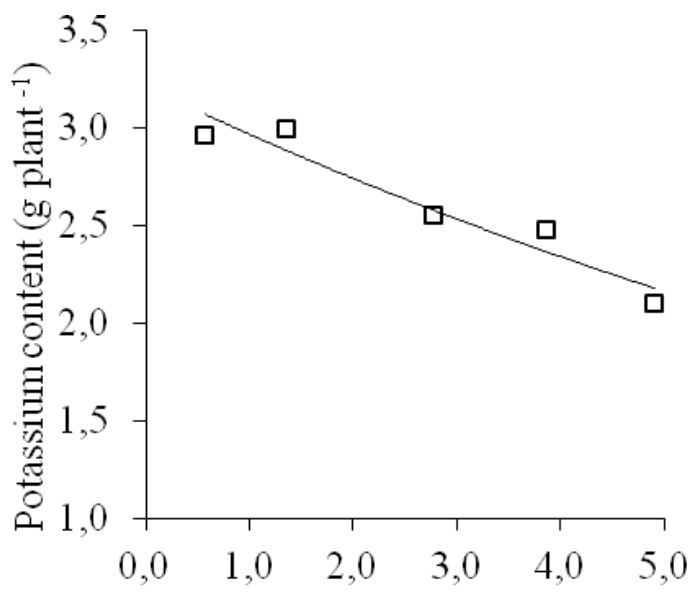

$\mathrm{EC}$ in the irrigation water $\left(\mathrm{dS} \mathrm{m}^{-1}\right)$

$$
\ln (\mathrm{y})=8.0-0.079 * *^{\mathrm{x}} \quad \mathrm{R}^{2}=0.93
$$

FIGURE 1. Nitrogen (A) and phosphorus (B) content in the vegetative part of the watermelon and phosphorus (C) and potassium (D) content in the aerial part of the plant, average of the cultivars Shadow and Quetzali, in function of the EC in the irrigation water.

Figure 2 represents the interaction $\mathrm{ECw}$ and watermelon cultivars in $\mathrm{K}$ accumulation in the vegetative part of the plant. Reduction in potassium accumulation was verified for Quetzali cultivar according to the increase of EC in irrigation water being the greater accumulation (1.50 $\left.\mathrm{g} \mathrm{plant}^{-1}\right)$ observed in the lowest $\mathrm{ECW}\left(0.57 \mathrm{dSm}^{-1}\right)$ and the lowest $\mathrm{K}$ content $\left(0.95 \mathrm{~g}\right.$ plant $\left.^{-1}\right)$ was observed in the highest salinity $\left(4.91 \mathrm{dS} \mathrm{m}^{-1}\right)$.

The absorption of $\mathrm{K}$ in plants grown in saline medium can be reduced by $\mathrm{Na}$ excess, since these ions compete for the same sites in the absorption system in the plasma membrane in the root cells (Marschner, 2012). Thus, the reduction on potassium absorption in watermelon subjected to saline stress is associated with the excess absorption by the roots and the transport to the aerial part of the $\mathrm{Na}^{+}$ion. The $\mathrm{K}$ accumulation in Shadow cultivar did not respond to the EC effect in the irrigation water, presenting an average value of $1.67 \mathrm{~g} \mathrm{plant}^{-1}$ (Figure 2A). This may mean a higher resistance of this cultivar to salinity. Among the studied cultivars, Shadow was the one with the lowest relative loss of production.

The $\mathrm{N}$ content in the aerial part of the plant decreased with the increase of $\mathrm{ECw}$, being the greater accumulation 2.49 and $2.03 \mathrm{~g} \mathrm{plant}^{-1}\left(\mathrm{ECw}=0.57 \mathrm{dS} \mathrm{m}^{-1}\right)$ and the smaller 1.84 and $1.52 \mathrm{~g} \mathrm{plant}^{-1}$ for the Shadow and Quetzali cultivars, respectively (Figure 2B). According to Lacerda et al. (2016) the lower $\mathrm{N}$ accumulation is due to the reduction in water absorption due to the osmotic effects of salinity and consequent reduction in growth.

B.

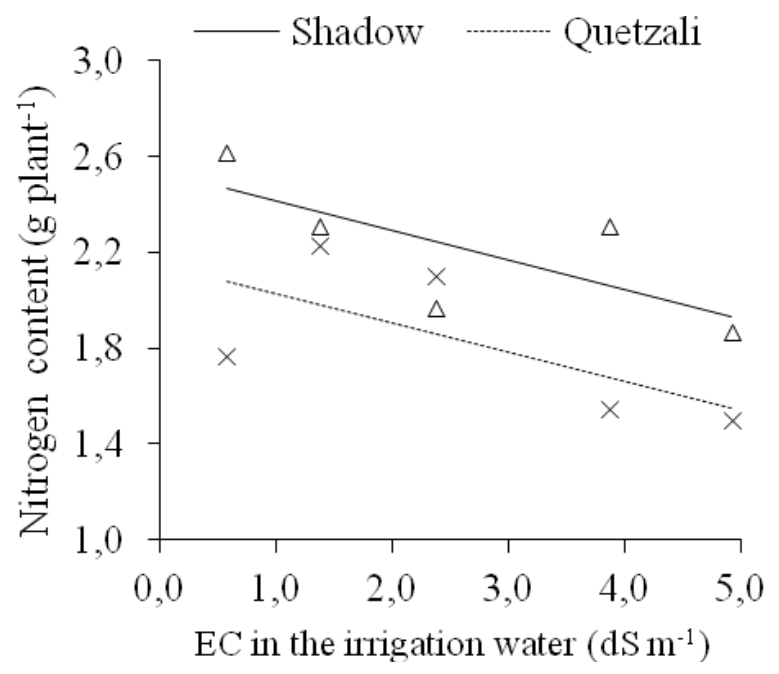

$-\square-\quad \mathrm{y}=1.67$

$$
\ln (\mathrm{y})=0.46-0.10^{* *} \mathrm{x} \quad \mathrm{R}^{2}=0.72
$$

$\mathrm{R}^{2}=0.58$

$\mathrm{R}^{2}=0.49$

FIGURE 2. Potassium content (A) in the vegetative part of watermelon and nitrogen (B) in the aerial part of the plant, Shadow and Quetzali cultivars, in function of the EC in the irrigation water. 
In relation to interaction days after transplanting and cultivars (Figure 3) we verified that the Shadow cultivar accumulated the maximum of $\mathrm{N}$ in the plant tissue at 51 days after transplanting (Figure 3A), being estimated an average accumulation of $7.12 \mathrm{~g} \mathrm{plant}^{-1}$; from 52 DAT the $\mathrm{N}$ accumulation began to decrease due to the translocation of this nutrient to the fruits, so that at 60 DAT the plant accumulated $5.54 \mathrm{~g}$. For the Quetzali cultivar (Figure 3A) the highest requirement of the vegetative part for this nutrient occurred at 46 DAT with accumulation estimated at $4.21 \mathrm{~g}$ plant ${ }^{1}$. Almeida et al. (2012) studying the absorption of macronutrients for Crimson Sweet watermelon cultivar also observed that the $\mathrm{N}$ requirement of the plant is increasing until the beginning of the fruiting.

A.

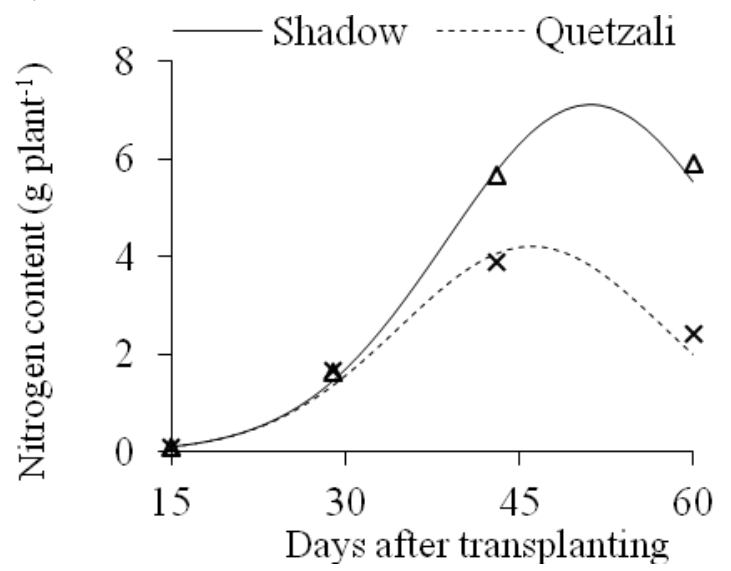

$-\ln (\mathrm{y})=6.44+0.33^{* *} \mathrm{x}-0.0032^{* *} \mathrm{x}^{2}$

C.

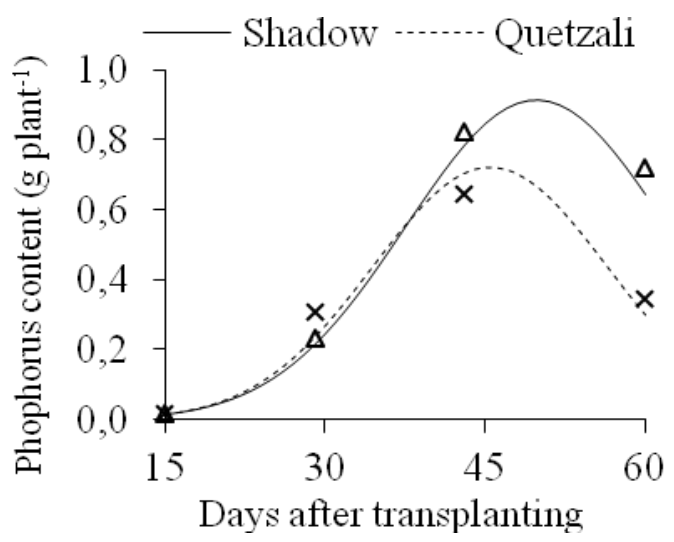

$--$
$\ln (\mathrm{y})=-5.41+0.33^{* *} \mathrm{x}-0.0033^{* *} \mathrm{x}^{2}$
$\ln (y)=-5.01+0.38^{* *} \mathrm{x}-0.0041^{* *} \mathrm{x}^{2}$
$\mathrm{R}^{2}=0.99 * *$
$\mathrm{R}^{2}=0.98 * *$

E.

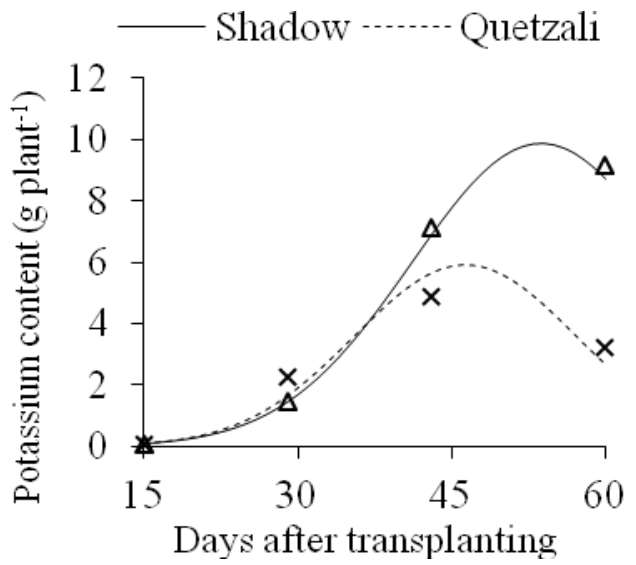

$-\ln (\mathrm{y})=0.083+0.34^{* *} \mathrm{x}-0.0032^{* *} \mathrm{x}^{2}$

$\mathrm{R}^{2}=0.99^{* *}$
$\mathrm{R}^{2}=0.98^{* *}$
B.

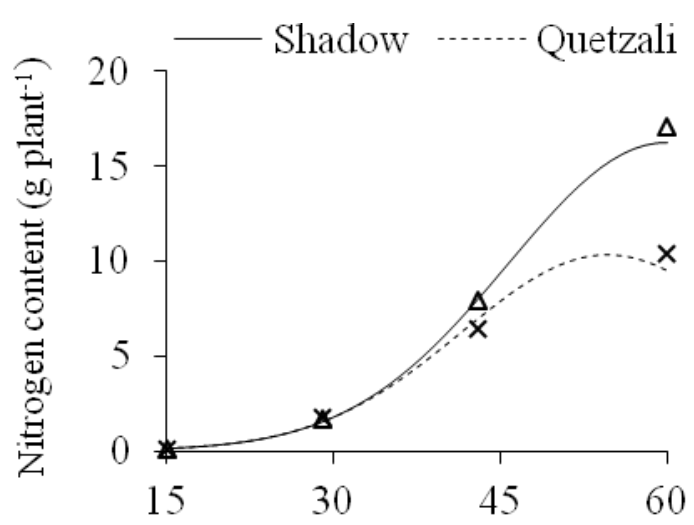

Days after transplanting

$\ln (\mathrm{y})=-6.17+0.30^{* *} \mathrm{x}+0.0025^{* *} \mathrm{x}^{2} \quad \mathrm{R}^{2}=0.99^{* * *}$

$\ln (\mathrm{y})=-6.43+0.32^{* *} \mathrm{x}+0.0029^{* * *} \mathrm{x}^{2} \quad \mathrm{R}^{2}=0.85^{* * *}$

D.

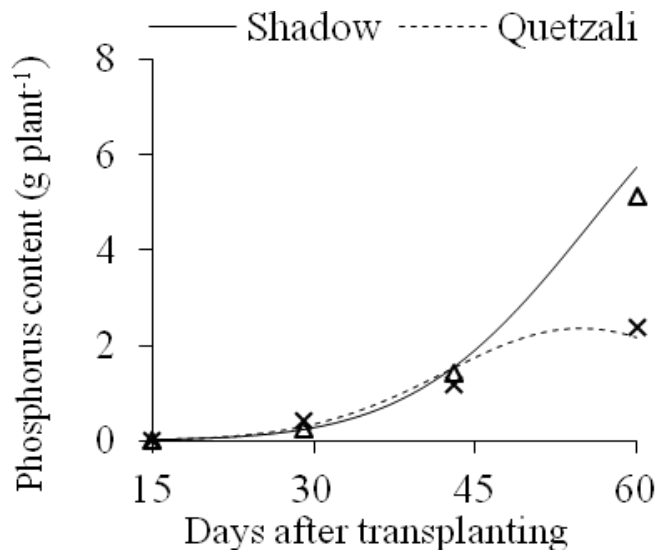

$\begin{array}{lll}\ln (\mathrm{y})=-7.79+0.27^{* *} \mathrm{x}+0.0019 * * \mathrm{x}^{2} & \mathrm{R}^{2}=0.99^{* *} \\ ---\ln (\mathrm{y})=-7.07+0.34^{* *} \mathrm{x}-0.0031^{* *} \mathrm{x}^{2} & \mathrm{R}^{2}=0.85^{* *}\end{array}$

F.

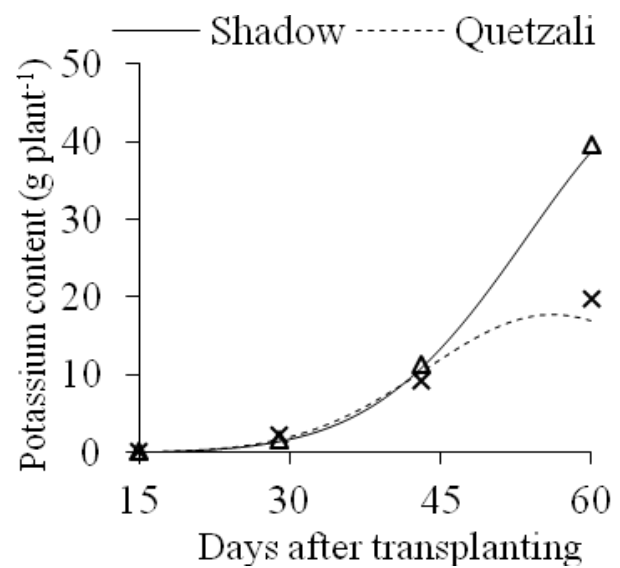

FIGURE 3. Nitrogen (A), phosphorus (C) and potassium (E) content in the vegetative part of the watermelon and nitrogen (B), phosphorus (D) and potassium (F) content in the aerial part of the plant, average of the Shadow and Quetzali cultivars, in function of the days after transplanting. 
The highest $\mathrm{N}$ accumulated content in the watermelon aerial part, Shadow cultivar (Figure 3B) was observed in the last evaluation period (60 DAT) with an average accumulation of $16.7 \mathrm{~g} \mathrm{plant}^{-1}$. For the Quetzali cultivar the highest $\mathrm{N}$ accumulation in the aerial part of the plant occurred at 54 DAT $\left(10.24 \mathrm{~g} \mathrm{plant}^{-1}\right)$ reducing to 60 DAT with an average accumulation of $9.50 \mathrm{~g} \mathrm{plant}^{-1}$ (Figure 3B).

According to Grangeiro et al. (2005) the absorption and nutrients accumulation in the watermelon is small in the first 30 days after transplanting, intensifying and reaching the maximum daily accumulation rate between 40 and 50 days. This determines that the soil mobile and easily leachable nutrients, such as nitrogen and potassium, should be applied in coverage to be available after the first 30 days.

The phosphorus content accumulated in the vegetative part of the plant for the Shadow and Quetzali cultivars are in Figure 3C. For the Shadow cultivar the highest accumulation $\left(0.91 \mathrm{~g} \mathrm{plant}^{-1}\right)$ occurred at 45 DAT and for the Quetzali cultivar the highest accumulation occurred at 50 DAT and it estimated an average value of $0.72 \mathrm{~g} \mathrm{plant}^{-1}$. In relation to phosphorus accumulation in the aerial part of the plant (Figure 3D), the highest observed content in the Shadow cultivar was $5.74 \mathrm{~g}_{\text {plant }}{ }^{-1}$ obtained in the last evaluation period (60 DAT) and for the Quetzali cultivar the highest accumulation (2.36 g plant $^{-1}$ ) occurred at 56 DAT from which there was a decrease reaching 60 DAT with an average value of $2.17 \mathrm{~g} \mathrm{plant}^{-1}$.
Grangeiro \& Cecílio Filho (2005) verified for the Mickylee watermelon hybrid that the accumulated amount of phosphorus in the plant reached maximum value at 50 DAT.

For the potassium content in the vegetative part of the watermelon (Figure 3E), we observed that the greatest accumulation of this nutrient occurred at 54 and 46 DAT for the Shadow and Quetzali cultivars, obtaining average values of 9.88 and $5.90 \mathrm{~g} \mathrm{plant}^{-1}$, respectively. In the aerial part of the plant the maximum accumulation was $38.77 \mathrm{~g}$ plant $^{-1}$ at the end of the crop cycle for the Shadow cultivar and for the Quetzali cultivar the highest amount required by the crop was $17.78 \mathrm{~g} \mathrm{plant}^{-1}$ at 56 DAT with a subsequent decrease in $\mathrm{K}$ amount in the aerial part of the plant (Figure $3 \mathrm{~F}$ ). The results indicate an increase in fruits $\mathrm{K}$ accumulation from the beginning of fruiting to the final development phase. Similar results were obtained by Grangeiro \& Cecílio Filho (2005) who working with Mickylee watermelon verified that $\mathrm{K}$ was the nutrient most accumulated by the cultivar, being the greatest demand of this nutrient occurred in the period from 40 to 50 DAT.

\section{Partition of N, P and $\mathrm{K}$}

Data on total accumulation and distribution of macronutrients in the vegetative part and in the fruits of the watermelon plants, Shadow and Quetzali cultivars, in the different levels of salinity are presented in Table 2.

TABLE 2. Percentage distribution of macronutrients at the end of the crop cycle of Shadow and Quetzali watermelon cultivars irrigated with water from different EC.

\begin{tabular}{|c|c|c|c|c|c|c|c|}
\hline \multirow[b]{2}{*}{ Accumulation } & \multirow[b]{2}{*}{$\mathrm{ECw}$} & \multicolumn{3}{|c|}{ Shadow } & \multicolumn{3}{|c|}{ Quetzali } \\
\hline & & $\mathrm{N}$ & $\mathrm{P}$ & $\mathrm{K}$ & $\mathrm{N}$ & $\mathrm{P}$ & $\mathrm{K}$ \\
\hline DWT & $057 \mathrm{dS} \mathrm{m}^{-1}$ & 17.38 & 8.36 & 41.75 & $\begin{array}{c}\text { ant }^{-1}-- \\
9.12\end{array}$ & 2.06 & 21.14 \\
\hline $\begin{array}{c}\text { DWVEG } \\
\text { DWFR }\end{array}$ & & $\begin{array}{l}28.37 \\
71.63 \\
\end{array}$ & $\begin{array}{c}8,73 \\
91.27 \\
\end{array}$ & $\begin{array}{l}14.47 \\
85.53\end{array}$ & $\begin{array}{l}26.92 \\
73.68\end{array}$ & $\begin{array}{l}19.90 \\
80.10\end{array}$ & $\begin{array}{l}17.50 \\
82.50\end{array}$ \\
\hline DWT & $1.36 \mathrm{dS} \mathrm{m}^{-1}$ & 23.11 & 8.09 & 51.14 & $\begin{array}{c}\text { ant }^{-1}-- \\
13.36\end{array}$ & 3.09 & 25.96 \\
\hline $\begin{array}{c}\text { DWVEG } \\
\text { DWFR }\end{array}$ & & $\begin{array}{l}43.53 \\
56.47 \\
\end{array}$ & $\begin{array}{l}17.55 \\
82.45 \\
\end{array}$ & $\begin{array}{l}25.78 \\
74.22 \\
\end{array}$ & $\begin{array}{l}23.43 \\
76.57 \\
\end{array}$ & $\begin{array}{l}14.24 \\
85.76 \\
\end{array}$ & $\begin{array}{l}18.53 \\
81.47 \\
\end{array}$ \\
\hline DWT & $2.77 \mathrm{dS} \mathrm{m}^{-1}$ & 12.67 & 5.18 & 32.12 & $\begin{array}{l}\mathrm{ant}^{-1}--- \\
10.17\end{array}$ & 1.91 & 18.87 \\
\hline $\begin{array}{c}\text { DWVEG } \\
\text { DWFR }\end{array}$ & & $\begin{array}{l}31.25 \\
68.75 \\
\end{array}$ & $\begin{array}{c}8.50 \\
91.50 \\
\end{array}$ & $\begin{array}{l}22.07 \\
77.93\end{array}$ & $\begin{array}{l}23.11 \\
76.89 \\
\end{array}$ & $\begin{array}{l}18.85 \\
81.15\end{array}$ & $\begin{array}{l}13.94 \\
86.06 \\
\end{array}$ \\
\hline DWT & $3.86 \mathrm{dS} \mathrm{m}^{-1}$ & 20.38 & 5.75 & 40.72 & $\begin{array}{c}\text { ant }^{-1}--- \\
8.78\end{array}$ & 2.18 & 15.37 \\
\hline $\begin{array}{c}\text { DWVEG } \\
\text { DWFR }\end{array}$ & & $\begin{array}{l}33.02 \\
66.98\end{array}$ & $\begin{array}{l}13.56 \\
86.44\end{array}$ & $\begin{array}{l}31.11 \\
68.89\end{array}$ & $\begin{array}{l}44.32 \\
55.58\end{array}$ & $\begin{array}{l}15.60 \\
84.40\end{array}$ & $\begin{array}{l}22.45 \\
77.55\end{array}$ \\
\hline DWT & $4.91 \mathrm{dS} \mathrm{m}^{-1}$ & 13.91 & 3.65 & 34.87 & $\begin{array}{l}\mathrm{ant}^{-1}--- \\
11.07\end{array}$ & 2.88 & 18.89 \\
\hline $\begin{array}{c}\text { DWVEG } \\
\text { DWFR }\end{array}$ & & $\begin{array}{l}39.54 \\
60.46\end{array}$ & $\begin{array}{l}15.07 \\
84.93\end{array}$ & $\begin{array}{l}25.50 \\
74.50\end{array}$ & $\begin{array}{l}10.93 \\
89.07\end{array}$ & $\begin{array}{c}7.64 \\
92.36\end{array}$ & $\begin{array}{l}11.59 \\
88.41\end{array}$ \\
\hline
\end{tabular}

DWT- dry matter total; DWVEG - dry matter total in the vegetative part; DWFR - dry matter in the fruits of the watermelon plants. 
By evaluating the nutrients distribution in the vegetative part and in the fruits of plants of the Shadow cultivar irrigated with water of lower EC, we verified that the $\mathrm{N}, \mathrm{P}$ and $\mathrm{K}$ had the highest accumulated amounts in the fruits with about $71.63,91.27$, and $85.53 \%$. Similar results were obtained for Quetzali cultivar that presented the highest accumulated amounts of $\mathrm{N}, \mathrm{P}$ and $\mathrm{K}$ in the fruits with about $73.68,80.10$ and $82.50 \%$. Similar behavior was obtained by Grangeiro et al. (2005) for the watermelon evidencing that the fruits are the main drains of the watermelon nutrients.

The nutrient requirement for the watermelon was in the following order: $\mathrm{K}>\mathrm{N}>\mathrm{P}$, being corroborated by Grangeiro et al. (2005) with Myckylee cultivar in Mossoró-RN conditions and confirmed by Lucena et al. (2011) with watermelon Quetzali in Mossoró-RN conditions. The potassium requirement by the watermelon is superior to the nitrogen, being demanded in greater proportion after fruiting. Potassium, although is not part of any organic compound, plays an important role in regulating the opening and closing of stomata, photosynthesis, gas exchange, enzyme activation and protein synthesis (Hawkesford et al., 2012) being therefore fundamental to the plant's growth and production.

\section{CONCLUSIONS}

1. The salinity of the irrigation water reduces the accumulation of N, P and K in watermelon, Shadow and Quetzali cultivars, and the effect is higher in the last one.

2. The order of nutrient extraction in the total dry matter of the aerial part of the watermelon cultivars is: $K>N>P$.

3. The age of the plant influences the accumulation of $\mathrm{N}, \mathrm{P}$ and $\mathrm{K}$ nutrients in the aerial part of the watermelon.

4. For both cultivars the highest amounts of N, P and $\mathrm{K}$ accumulate in the fruits.

\section{ACKNOWLEDGMENTS}

The authors are grateful to the FRUTERN - FINEP / ESAM / FGD Accord for the field infrastructure and to the CTARN - FINEP / FAPERN / UFERSA / EMPARN / UFRN Accord for the laboratory infrastructure; to $\mathrm{CNPq}$ which provided the necessary resources to carry out this project and to CAPES for granting the scholarship.

\section{REFERENCES}

Allen RG, Pereira LS, Raes D, Smith M (2006)

Evapotrasnpriation del cultivo: Guias para a la determinacion de los requeriments de água de los cultivos. Roma, FAO, 298p. (FAO, Estúdio de Riego e Drenaje Paper, 56)

Almeida EIB, Corrêa MC de M, Nóbrega GN, Pinheiro EAR, Lima FF (2012) Crescimento e marcha de absorção de macronutrientes para acultivar de melancia Crimson Sweet. Revista Agro@mbiente On-line 6(3):205-214.

Bardin I (1994) Análise de conteúdo. Lisboa, Edições Setenta, $226 \mathrm{p}$.
Brito MEB, Fernandes PD, Gheyi HR, Melo AS, Soares Filho WS, Santos RT (2014) Sensibilidade à salinidade de híbridos trifoliados e outros porta-enxertos de citros. Revista Caatinga 27(1):17-27.

Costa ARFC da, Medeiros JF de, Porto Filho F de Q, Silva JS da, Costa FGB, Freitas DC de (2013) Produção e qualidade de melancia cultivada com água de diferentes salinidades e doses de nitrogênio. Revista Brasileira de Engenharia Agrícola e Ambiental 17(9):947-954.

Costa FGB, Fernandes MB, Barreto HBF, Oliveira A de FM, Santos W de O (2012) Crescimento da melancia e monitoramento da salinidade do solo com TDR sob irrigação com águas de diferentes salinidades. Irriga 17(3):327-336.

Embrapa - Empresa Brasileira de Pesquisa Agropecuária (2006) Sistema brasileiro de classificação de solos. Rio de Janeiro, Embrapa - SPI, 2 ed. 306p.

Embrapa - Empresa Brasileira de Pesquisa Agropecuária (2009) Manual de análises químicas de solos, plantas e fertilizantes. Rio de Janeiro, Embrapa Solos, 2ed. 627p.

Furtardo G de F, Pereira FHF, Andrade EMG, Pereira Filho RR, Silva SS da (2012) Efeito do Nitrato de Cálcio na Redução do Estresse Salino em Melancieira. Revista Verde 7(3):33-40.

Grangeiro LC, Cecílio Filho AB (2005) Acúmulo e exportação de macronutrientes em melancia sem sementes. Horticultura Brasileira 23(3):763-767.

Grangeiro CL, Mendes AMS, Negreiros MZ, Souza JOS, Azevêdo PE (2005) Acúmulo e exportação de nutrientes pela cultivar de melancia Mickylee. Revista Caatinga 18(2):73-81.

Hawkesford M, Horst W, Kichey T, Lambers H, Schjoerring J, Møller IS, White P (2012) Functions of macronutrients: potassium. In: Marschner H (ed). Mineral nutrition of higher plants. Amsterdam, 3ed. cap. 6, p. 178 189.

Lacerda CF, Ferreira JFS, Liu X, Suarez DL (2016) Evapotranspiration as a criterion to estimate nitrogen requirement of maize under salt stress. Journal of Agronomy and Crop Science 202(3):192-202.

Lucena RRM, Negreiros MZ, Medeiros JF, Grangeiro LC, Marrocos STP (2011) Crescimento e acúmulo de macronutrientes em melancia 'Quetzale' cultivada sob diferentes níveis de salinidade da água de irrigação. Revista Caatinga 24(1):34-42.

Marschner H (2012) Mineral nutrition of higher plants. California, Academic Press, 3ed. 651p.

Martins DC, Ribeiro M da S de S, Souza Neta ML de, Silva RT da, Gomes LP, Guedes RAA, Oliveira F de A (2013) Desenvolvimento inicial de cultivares de melancia sob estresse salino. Agropecuária Científica no Semiárido 8(3):62-68.

Medeiros JF, Terceiro Neto CPC, Gheyi HR., Dias NS, Souza MSM, Souza RO (2014) Management strategies of saline water on morphometric characteristics of melon cultivars. Engenharia Agrícola 34(4):649-659. 
Neves ALR, Lacerda CF de, Guimarães FVA, Hernandez FFF, Silva FB da, Prisco JT, Gheyi HR (2009)

Acumulação de biomassa e extração de nutrientes por plantas de feijão-de-corda irrigadas com água salina em diferentes estádios de desenvolvimento. Ciência Rural 39(3):758-765.

Oliveira FA, Sá FVS, Paiva EP, Araújo EBG, Souto LS, Andrade RA, Silva MKN (2015) Emergência e crescimento inicial de plântulas de beterraba cv. Chata do Egito sob estresse salino. Agropecuária Científica no Semiárido 11(1):01-06.
Silva MCC, Medeiros JF, Negreiros MZ, Sousa VF (2005) Produtividade de frutos do meloeiro sob diferentes níveis de salinidade da água de irrigação, com e sem cobertura do solo. Horticultura Brasileira 23(2):202-205.

Wanderley JAC, Araújo Filho JB de, Souza J de S, Alves L de S, Maracajá PB (2010) Efeito de doses de rejeito de caulim em solo sódico no desenvolvimento inicial da mamoneira (Ricinus communis L.). Revista Verde de Agroecologia e Desenvolvimento Sustentável 5:26-38. 